Dr Michal Izak - University of Lincoln

Dr Samuel Mansell - University of St Andrews

Professor Ted Fuller - University of Lincoln

Editorial - SI Futures of Capitalism

\title{
Between No Future and Business-As-Usual: Exploring Futures of Capitalism
}

The purpose of this special issue is to examine possible futures of capitalism and their relationship to the economic, environmental and social futures of humankind. Capitalism is a system that legitimises the pursuit of economic growth through the reinvestment of surplus. In this respect private ownership of capital is legitimate and often lies in separate hands from those who control the means of producing wealth. It could be argued that both wage earners and capitalists are in a precarious position: the former because they lack ownership of the fruits of their labour, and the latter, because the accumulation process in which they participate is prone to crises and disruptions, making their position also perilous. Arguably, societies have managed the relationship between this system of economic value creation and other systems necessary for human survival and development through various forms of governance. As recent events have reminded us, capitalist systems can go wrong. Even when capitalism works as expected, the externalities can be disastrous, such as the effects of unregulated speculation on world food prices.

Some, such as the so called Chicago School (e.g. Friedman and Friedman, 1962; Zingales 2012) would argue that capitalism, albeit in several forms, has been very successful in increasing wealth and well-being globally and that while not perfect is the 'best' approach available. It could be claimed that 
capitalism has also co-evolved with society and its structures, seats of power and organisation of activities to the extent that it has become incomparable with the economic system analysed by David Ricardo (Ricardo, 1817). According to some accounts (e.g. Boltanski and Chiapello, 2005), the major force driving this evolution is capitalism's ability to respond to its critics by reorganizing the value system it depends upon. It would seem timely for such a re-organization. Forms of Capitalism have created greater wealth for many people, but capitalism appears to be moving close to consuming itself at the margin of utility. The signs are that the dominant forms of capitalism are destroying their own futures by using them in the present. Economic growth has been fuelled by higher levels of indebtedness, i.e. using its own future for the present. Natural resources are unsustainably depleted to excite todays' demands, leaving little for future capitalism or humankind. Short-term global financial imperatives disconnected from meaningful human value are leading to greater inequality and hence to futures with less capital for most people.

Acknowledging the differences in how capitalism is manifested in various contexts this Special Issue invited reflections, unrestricted by any status quo, on the future directions which capitalism may take and the potential social, economic and organizational implications.

The reflections gathered in this Special Issue testify to the variety of reasons for inquiring into the futures of capitalism. Multiple theoretical foundations are drawn upon; however, the interdisciplinarity in evidence here is a potent vehicle for exploring a number of potential futures rather than enforcing a uniform claim about what this future will be. Every good futurology being informed by knowledge of the present conditions, the articles demonstrate a strong theoretical and empirical awareness preceding the vision and analysis, which they offer. Approaching the futures of capitalism from a financial, economic, religious, broadly organizational or strictly managerial angle, the diagnoses differ in their starting points but largely cohere in the radical tone of the conclusions and measures proposed.

The contributors raise profound concerns with various aspects of capitalism, 
whether in terms of its inherent tensions, structural inefficiencies, questionable rationales or misconstrued assumptions. Together they evoke a picture of the multidimensional unsustainability of the capitalist system as such. Given that the issues at hand include the recent economic crisis, stagnation in the Eurozone, the re-emergence of radical movements in and beyond Europe, imperialistic warmongering at the eastern borders of the EU as well as (often claimed) cultural and educational impoverishment of societies in the developed countries, such a solemn verdict should not be a surprise.

Admittedly, cultural and political issues stand in a less obvious relationship to the ailments of capitalism than economic ones. However, with governmental decision making in most developed countries being dominated by neoliberal policies (in spite of disastrous effects of imposing such policies in developing countries [Siddiqui, 2012]) the interweaving of economic arguments with social, political and cultural dimensions (Rorty, 1989) is unavoidable. For instance, the 'impact' orientation has been readily translated from the economic sphere to education, science, entertainment and organizational 'daily' life. We therefore see contact times in higher education (both peer-topeer and lecturer-to-student) becoming 'optimized', and hence shrinking, with communication of expertise valued in terms of the 'effects' produced. The inverse relationship between the increased pace of interaction and the intrinsic value of the exchange itself is associated with the emerging 'liquidity' (Bauman, 2000) of the social sphere, flexibility of the social and organizational structures (Gabriel, 2005), their emphasis on image rather than substance (Alvesson, 1990). The resulting 'translucency' of the social bond has been described as the drive to counteract a perceived lack of impact by accentuating one's presence in the virtual world (Izak, 2014).

Naturally, the translations between economic and other spheres of social activity are not unidimensional: for example, the conduct of politics increasingly draws on Hollywood-derived props when theatrical showperformance is staged, and celebrities of all kinds enter politics with increasing success. Hence, while the focus of this Special Issue warrants granting special attention to the economic aspect of capitalism - as many of 
the contributors do - its social, political and cultural dimensions can also provide key insights into capitalism's futures, as we hope the reader of this volume will agree.

Our collection thus opens with Catherine Macaulay's study of a problem inherent to the structure of capitalism: the instability of secondary (financial) markets that are oriented towards 'the sole benefit of the trader and not the company'. Through exploring the tensions embedded in one of the foundational enterprises for the capitalist business model - the $17^{\text {th }}$ century Dutch East India Company - the author identifies the parallel idiosyncrasies of the whole capitalist system. She argues that the future of capitalism is in jeopardy if further development of fluid and unstable secondary markets is pursued. She offers a nuanced argument for the expansion of primary markets (for direct investment in productive enterprise) at the expense of financial 'meta investments', the marginalization of the latter construed as beneficial to capitalism. Without glorifying the 'golden past' or calling for an unlikely obliteration of secondary markets, Macaulay evokes the potential for capitalism's renaissance through direct and creative forms of business investment and lending, the plentiful (and positive) examples of which are discussed in her article.

Jacques-Olivier Charron also expresses disillusionment with the intrinsic logic of secondary markets for financial assets. He discusses the structural tensions of capitalism in terms of a legitimacy crisis of financial markets. Charron argues that financial assets lack intrinsic utility, from which it follows that the markets in which they are traded cannot be justified in either the market (competition-oriented) and industrial (efficiency-related) orders. Charron questions whether the current financial market is truly 'efficient': financial assets are neither scarce nor desirable in themselves and their pricing is merely 'technically' (in terms of price forecasting) rather than 'fundamentally' efficient (in terms of price reflecting the fundamental value of an asset). Thus Charron proposes a turn towards 'investee capitalism' in which prices would be publicly debated on the basis of established criteria of valuation involving 'independent valuation authorities'. The aim would be the 
decoupling of the exchange of an asset from its valuation, thus basing financial valuation on politics and public debate, rather than on market speculation. And the interests of investees would no longer be overshadowed by the investors' impact on pricing. Charron proposes that this civic-market compromise would restore both stability and justice to the valuation of financial assets and resolve the illegitimacy of financial markets and the resulting tension in the capitalist system. The author outlines the conditions of possibility for this reformulation (rather than 'obliteration') of the capitalist system in relation to the ongoing debates around private and public debt following the 2008 market crash.

The futures of the capitalist system explored in the next article seem as profound as they are plausible. Still in the spirit of exploring the boundaries of capitalism from a systemic (in this case economic) perspective, GarcíaOlivares and Solé focus on the inherent limits of economic growth resulting from unsustainable use of natural resources and limited resilience of global ecosystems. Their detailed analysis suggests upcoming challenges which if unchecked (and the authors remain sceptical towards the likelihood of successfully tackling these issues) may lead to a 'zero growth' economy by 2025-2045. They expound the implications for the development of alternative forms of social and economic life around 'steady-state' capitalism. In GarcíaOlivares and Solé's argument, the socio-political and economic prognosis can be captured in terms of a symbiotic economy - 'a combination of an ecologically balanced society and information society', due to an enhanced regulatory function coupled with a bipolar redistribution of power: towards the state and towards professionals, i.e. managers. To prevent a further (potential) totalitarian drift of this powerful alliance, the manifold dimensions of which we may observe even today, the authors call for stronger bottom-up democratic involvement in a 'coordinated market economy'.

The next three articles shift the plane of discussion towards the social and organizational realm - pondering the characteristics of the management function, the role of managers and the dilemma faced by those who are managed - while remaining faithful to the task of rethinking the deeply held 
assumptions of the capitalist system. Both the grim diagnosis of an internal break within the system and an exhortation to a more participative and engaged approach (evoked by García-Olivares and Solé) are embraced in Berman and Van Buren's article. Their revivification of Mary Parker Follet's writings for modern managerial practice provides an opportunity to reconsider a fundamental assumption inherent in capitalist systems: the instrumental treatment of employees by management in pursuit of profit maximisation and capital accumulation. As the authors observe, Follet developed groundbreaking concepts for her time, such as empathy towards workers' concerns and power sharing between different organizational layers for mutual benefit (power 'with' rather than 'over'), but these insights have been largely forgotten, or never learnt. Informed by Follet's principles, the authors propose that a more participative organizational model with better integration of employees' concerns may lead to restoring a - much-weathered - faith in capitalism.

Another entry point to reconsider the capitalistic managerial logic is offered by Christian Garmann Johnsen. He focuses upon the aporia inherent in how popular management theories of innovation conceptualise the future of management. Garmann Johnsen finds the ideological repetition of popular management concepts inconsistent with the claim to sustain organizational innovations - a recurrent mantra of management gurus. The author explores this inherent contradiction 'within the immanence' of the thinking of one 'guru' in particular: Gary Hamel. A Derridian deconstruction of Hamel's work leads Garmann Johnsen to conclude that management presents a pharmakon for innovation: it is both a 'cure' for traditional impediments to innovation and a 'toxin' that impedes innovation in the organization. This vignette enables Garmann Johnsen to conclude that 'management innovation is a conceptual structure that necessarily must be transgressed in order for the concept to serve its purpose'.

The transgression and reconsideration of another aspect of managerial logic even if sometimes cloaked as its opposite - is proposed by Thomas Taro Lennerfors. In response to the changing nature of capitalism and the claims 
made in its name, Lennerfors comprehensively examines Buddhist economics as a potential future for capitalism. He builds upon parallel discussions of new modes of social and economic interactions in a variety of contexts - including consumption and leisure (as discussed by Zygmunt Bauman) as well as management and employment (analysed by Boltanski and Chiapello) - and explores 'soft' attempts to re-construct 'light' capitalism through the lens of organizational spirituality. The author's approach is reflexive in that he approaches Buddhism from a critical perspective and demonstrates how its own foundations were misconceived in translation to a 'Western' context: for instance, as a manner of coping with capitalist abuse and/or as a philosophy of harmony. The author exhorts a return to the spiritual potential of Buddhism, which may create the critical platform for re-appropriating the conceptual terrains colonized by capitalism, and as a result enable capitalism to be reformed.

We would like to propose that two distinct approaches can be identified. Half the articles in this issue explore the material or conceptual boundaries that pertain to any possible capitalist future. For example, Macaulay examines the limited capacity of financial markets to provide economic stability, GarcíaOlivares and Solé investigate the environmental limits to future economic growth, and Garmann-Johnsen exposes a contradiction in any attempt to break with prevalent management conventions by reducing innovation (or creativity) to a formula. On the other hand, the remaining three articles focus more on the justice and legitimacy of various ways of organising within the range of possibilities offered by the futures of capitalism. Berman and Van Buren contend that the legitimacy of capitalism is undermined by the widespread exclusion of employees' interests from the concerns of managers, while Charron similarly argues that the legitimacy crisis of financial markets may be overcome by placing the interests of the marginalised stakeholder back in the picture: in this case, the investee. The search for an ethical future of capitalism also appears in Lennefors' article, with his call for a focus on the ends of capitalism as well as the means, which he addresses through Buddhist economics. 
Without imposing a semblance of uniformity on these multifaceted explorations of capitalism's futures, we would like to point towards their structural resemblance, associated with - one could claim - a certain similarity of analytic insight. First, the past seems to hold the key to understanding - if not shaping - the future: the conceptual roots of capitalism should be made explicit and the taken for granted assumptions re-thought. Second, while awareness of the problematic nature of capitalism is crucial, attention should be paid to the spontaneous emergence of alternative forms of organizing political, social, cultural and economic life within and beyond capitalism. Finally, capitalism's future can be approached in terms of combining both its historical conceptions and alternative forms of organizing in the spirit of reflexivity.

If, as Karl Weick said, paraphrasing the words of Alice, we rarely know what we think 'until we see what we say' (Weick, 1995), and if therefore we must believe in the possibility of a certain occurrence in order to be able to grasp it, then the value of reflection on the possible alternatives (the signs of which we see around us), especially in times of political and economic turmoil, cannot be understated. While not being the only meal on the menu, the articles collected here recognize that the scope for possible futures is broader than 'business as usual', invite further reconsideration of the current capitalist model and are a potential springboard for action.

The editors invite further contributions that explore the futures of capitalism in subsequent volumes of Futures Journal. 
Bibliography:

Alvesson, M. (1990) Organization: From Substance to Image? Organization Studies, $11(3):$ 373-394.

Bauman, Z. (2000). Liquid Modernity. Cambridge: Polity Press.

Boltanski, L. \& Chiapello, E. (2005) The New Spirit of Capitalism. LondonNew York: Verso.

Friedman, M., \& Friedman, R. D. (1962). Capitalism and Freedom. Chicago ; London: University of Chicago Press.

Gabriel, Y. (2005). Glass Cages and Glass Palaces: Images of Organization in Image-Conscious Times. Organization, 12(1), 9-27.

Izak, Michal (2015) Translucent society and its nonfortuitous design: producing and consuming reality through images. Culture and Organization, 20 (5): 359-376.

Ricardo, D. (1817/1951) On the Principles of Political Economy and Taxation. Cambridge: Cambridge University Press.

Rorty, R. (1989) Contingency, Irony and Solidarity. Cambridge: Cambridge University Press.

Siddiqui, K. (2012) 'Developing Countries' Experience with Neoliberalism and Globalisation' Research in Applied Economics , 4 (4): 12-37.

Weick, K. E. (1995). Sensemaking in organizations. Thousand Oaks, CA: Sage Publications.

Zingales, L. (2012). A Capitalism for the People : Recapturing the Lost Genius of American Prosperity. New York: Basic Books. 